\title{
ВІДОМЧІ ЗАКЛАДИ ОХОРОНИ ЗДОРОВ'Я У СИСТЕМІ ЄДИНОГО МЕДИЧНОГО ПРОСТОРУ: ОРГАНІЗАЦІЙНО-ПРАВОВІ ЗАСАДИ
}

Сіделковський О. Л.

Стаття присвячена проблемі залучення відомчих медичних установ до формування єдиного медичного проcтору. У статті зазначено, що одним із важливих елементів реалізації на практиці медичної реформи $\epsilon$, на наше глибоке переконання, створення та належне організаційно-правове забезпечення єдиного медичного простору. Це функціональне утворення, яке здатне уніфікувати підходи до надання медичної допомоги, їі доступності та якості.

Питання, що є недостатньо розробленим у системі адміністративно-правового регулювання медичної діяльності загалом і формування єдиного медичного простору зокрема, полягає у ролі та значенні відомчих медичних закладів у вказаних процесах. Коли ми говоримо про відомчу медицину, то передовсім маємо на увазі організацію надання медичної допомоги в системі МВС України, міноборони України, СБУ, Укрзалізниці, Державного управління справами. Тут мають можливість отримувати якісну медичну допомогу особи, котрі мають відношення до вказаних вище відомств, $і$ члени їхніх сімей.

Якщо ми говоримо, що позитивом є використання військових медичних закладів не тільки для потреб військовослужбовців і членів їхніх сімей, то важливо проаналізувати i зворотні процеси - використання звичайних державних i комунальних закладів охорони для потреб військовослужбовців.

Автор ставить питання: чи є узагалі можливим і доречним сприйняття пенітенціарної медицини як складової частини єдиного медичного простору? чи все ж таки ії особливий характер (навіть порівняно з іншими відомчими медичними закладами) робить це неможливим? Запропоноване власне бачення цих процесів.

Загальний висновок полягає у тому, що відомчі медичні заклади можуть і повинні бути залучені до функціонування

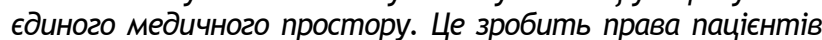
у сфері охорони здоров'я більш реалістичними, справедливими та доступними для громадян.

Ключові слова: медичне право, відомча медицина, єдиний медичний простір, права пацієнтів.

Статья посвящена проблеме привлечения ведомственных медицинских учреждений к формированию единого медицинского пространства. В статье указано, что одним из важных элементов реализации на практике медицинской реформы является, по нашему глубокому убеждению, создание и надлежащее организационно-правовое обеспе чение единого медицинского пространства. Это функциональное образование, которое способно унифицировать подходы по оказанию медицинской помощи, ее доступности и качества.

Bonрос, который недостаточно разработан в системе административно-правового регулирования медицинской деятельности в целом и формирования единого медицинского пространства в частности, заключается в роли и значении ведомственных медицинских учреждений в ука-

Сіделковський О. Л., 2019 занных процессах. Когда мы говорим о ведомственной медицине, то имеем в виду организацию оказания медицинской помощи в системе МВД Украины, Минобороны Украины, СБУ, Укрзализныци, Государственного управления делами. здесь имеют возможность получать качественную медицинскую помощь лица, имеющие отношение к указанным выше ведомствам, и члены их семей.

Если мы говорим, что позитивом является использование военных медицинских учреждений не только для нужд военнослужащих и членов их семей, то важно проанализировать и обратные процессы - использование обычных государственных и коммунальных учреждений для нужд военнослужащих.

Автор задает вопрос: является ли вообще возможным и уместным восприятие пенитенциарной медицины как составляющей единого медицинского пространства? Или все же ее особый характер (даже по сравнению с другими ведомственными медицинскими учреждениями) делает это невозможным? Подается личное видение этих процессов.

Общий вывод состоит в том, что ведомственные медицинские учреждения могут и должны быть привлечены к функционированию единого медицинского пространства. Это сделает права пациентов в сфере здравоохранения более реалистичными, справедливыми и доступными для граждан.

Ключевые слова: медицинское право, ведомственная медицина, единое медицинское пространство, права пациентов.

The article is devoted to the problem of involvement of departmental medical institutions in the formation of a single medical space. The article states that one of the important elements of implementation in the practice of medical reform is, in our deep conviction, the creation and proper organizational and legal support of a single medical space. It is a functional entity that can unify approaches to health care delivery, accessibility and quality.

The issue, which is not well developed in the system of administrative and legal regulation of medical activity in general and the formation of a single medical space in particular, lies in the role and importance of departmental medical institutions in these processes. When we talk about departmental medicine, first of all we mean the organization of providing medical care in the system of the Ministry of Internal Affairs of Ukraine, the Ministry of Defense of Ukraine, the Security Service of Ukraine, the Ukrainian Railways, the State Administration of Affairs. Here, they have the opportunity to receive quality medical care from individuals who are relevant to the above agencies and their families.

If we say that the positive is the use of military medical institutions not only for the needs of servicemen and their families, then it is important to analyze the reverse processes as well the use of conventional state and communal security institutions for the needs of servicemen.

The author asks the question: is it generally possible and appropriate to accept penitentiary medicine as part of a sin- 
gle medical space? Does its special character (even in comparison with other departmental medical institutions) make this impossible? And it gives its vision to these processes.

The overall conclusion is that departmental healthcare facilities can and should be involved in the functioning of a single medical space. This will make the rights of patients in the healthcare sector more realistic and equitable and accessible to citizens.

Key words: medical law, departmental medicine, common medical space, patients' rights.

Постановка проблеми та їі актуальність. Проблематика правового регулювання медичної діяльності набуває останнім часом особливої гостроти. У контексті сприйняття України як соціальної держави важливими видаються слова С.Г. Стеценка про те, що «в умовах сьогодення під соціальною державою необхідно розуміти якісно новий рівень реалізації державою соціальної функції, пріоритет соціального компоненту у правотворчій і правозастосовній діяльності, взяття державою на себе та виконання соціальних зобов' язань щодо всіх громадян чи їх певних категорій» [1, с. 252].

Виклад основного матеріалу. Нині ми $є$ свідками активного етапу здійснення медичної реформи в Україні. $€$ всі підстави говорити про те, що, за певними ознаками, це найбільш дієвий варіант іï проведення порівняно з іншими спробами реформування вітчизняної системи охорони здоров' я. Наскільки він $\epsilon$ ефективним і суспільно корисним, ми зможемо оцінити пізніше, проте вже зараз можемо констатувати таке:

1) ці зміни відчувають всі: пацієнти, лікарі, суспільство і держава загалом. Перші дві категорії поки що переважно на рівні підсвідомості, проте $\epsilon$ і суто реальні кроки, як-то старт із 1 квітня поточного року вибору лікаря первинної ланки надання медичної допомоги;

2) створено абсолютно новий державний орган Національну службу здоров'я України. За формальними ознаками це центральний орган виконавчої влади, за фактичними - основний «тримач коштів», які держава виділятиме на фінансування надання медичної допомоги;

3) швидкість проведення медичної реформи. Вона $\epsilon$ істотною. Поява нового закону, видання низки підзаконних нормативно-правових актів, впровадження нових організаційно-правових механізмів всередині сфери охорони здоров'я - все це відбувається протягом останніх місяців [2, с. 128-129].

Одним із важливих елементів реалізації на практиці медичної реформи $\epsilon$, на наше глибоке переконання, створення та належне організаційно-правове забезпечення єдиного медичного простору. Це функціональне утворення, яке здатне уніфікувати підходи до надання медичної допомоги, її доступності та якості. Якщо говорити про історіографічні засади дослідження правових засад формування єдиного медичного простору України, то необхідно вказати на декілька важливих обставин:

по-перше, сама сучасна постановка питання про єдиний медичний простір - це надбання останніх 8-10 років. Досі у такому форматі проблематику функціонального об'єднання різних систем охорони здоров'я фахівці на науковому рівні фактично не порушували;

по-друге, необхідно цей зріз правового регулювання медичної діяльності сприймати у розрізі адміністративно-правового забезпечення української охорони здоров'я, позаяк переважну більшість суспільних від- носин, що виникає, врегульовано саме нормами адміністративного права;

по-третє, констатуємо значний вплив політичних факторів на ініціювання реформ у сфері охорони здоров'я. Зазвичай нові політичні сили - переможці тих чи інших виборчих перегонів - намагаються запропонувати суспільству новий вектор розвитку організації охорони здоров'я, який зазвичай потребує свого належного юридичного унормування.

Р.А. Майданик стверджує, що у сфері вітчизняної охорони здоров'я можна виокремити десять основних юридичних викликів (чинників), які зумовлюють правове забезпечення: 1) єдиного медичного простору як ключового стандарту; 2) систематизації законодавства; 3) імплементації та дотримання міжнародно-правових норм; 4) справедливого, прозорого та відповідального управління системою охорони здоров'я і впливу громадськості на ухвалення державних рішень; 5) рівноправності доступу і багатоканальності фінансування; 6) необхідної якості медичної допомоги; 7) високої якості та доступності лікарських засобів, вакцин та інших імунобіологічних препаратів, виробів медичного призначення; 8) гідності медичного працівника, його участі у формуванні стандартів медичної професії і контролю за їх дотриманням; 9) захисту права на охорону здоров'я та медичну допомогу відповідно до принципів, визначених конституцією; 10) належного рівня біобезпеки у країні як складової частини світової системи біобезпеки [3, с. 36-37].

Питання, яке $\epsilon$ недостатньо розробленим у системі адміністративно-правового регулювання медичної діяльності загалом і формування єдиного медичного простору зокрема, полягає у ролі та значенні відомчих медичних закладів у вказаних процесах. Коли ми говоримо про відомчу медицину, то передовсім маємо на увазі організацію надання медичної допомоги в системі МВС України, Міноборони України, СБУ, Укрзалізниці, Державного управління справами. Тут мають можливість отримувати якісну медичну допомогу особи, котрі мають відношення до вказаних вище відомств, і члени їхніх сімей.

Якщо взяти систему МВС України, то вона володіє розгалуженою мережею лікувально-профілактичних і санаторно-курортних медичних закладів, які спеціалізуються на наданні медичної допомоги певним категоріям громадян. Як стверджується, основними чинниками, що свідчать про актуальність розгляду питань діяльності органів внутрішніх справ у контексті реалізації державної політики у галузі охорони здоров'я, $\epsilon$ такі:

суттєві зміни нормативно-правової бази охорони здоров'я України, які призвели до появи цілої низки документів, положення котрих присвячені різним аспектам медичної діяльності;

реформування органів внутрішніх справ України принципово не торкалося організаційно-штатної структури та нормативно-правового регулювання системи медичного забезпечення;

соціальні завдання, що виконують відомчі медичні заклади системи МВС України шляхом надання медичної допомоги не тільки працівникам органів внутрішніх справ, а й іншим категоріям громадян (членам сімей працівників ОВС, пенсіонерам ОВС тощо);

морально-етичні та правові проблеми надання медичної допомоги в системі МВС України, пов'язані з необхідністю збереження лікарської таємниці; 
необхідність урахування особливостей праці медичних працівників системи МВС України [4, с. 1].

С.Г. Стеценко та Т.О. Тихомирова зазначають, що реалії організаційно-штатної побудови органів внутрішніх справ України наочно свідчать про наявність проблем доступності медичної допомоги. Адже одна справа, коли працівник міліції проходить службу в М. Києві чи обласному центрі й зовсім інша - коли йдеться про сільського дільничного інспектора міліції, котрий забезпечує виконання покладених на нього функцій у декількох селах, жодне із яких нерідко не має фельдшерсько-акушерського пункту. Думається, що тут необхідно виходити як із реалій цивільної медицини (системи Міністерства охорони здоров'я, так і з можливостей відомчої медицини системи Міністерства внутрішніх справ України). Один із можливих варіантів проведення щорічних медичних оглядів у лікувальних закладах обласного рівня відомчої медицини, а у разі невідкладної допомоги (чи амбулаторно-поліклінічної) - звернення до найближчого медичного закладу цивільної системи охорони здоров'я [5, с. 34]. Чи не про прояви формування єдиного медичного простору говориться у науковій монографії?

У свою чергу, говорячи про Міноборони України, пошлемося на думку А.Є. Бакай, за якою інтеграція цивільної та військової медицини в Україні не має належного нормативно-законодавчого підґрунтя, $\epsilon$ недостатньою, стихійно сформованою, що негативно впливає на медичну, соціальну й економічну ефективність системи медичного забезпечення сил оборони і населення. У рекомендаціях парламентських слухань на тему: «Про військово-медичну доктрину України» наголошується, що прийняття такого базового документа загальнодержавного рівня, як військово-медична доктрина, є пріоритетним завданням і державних органів, і громадянського суспільства. Основними завданнями доктрини повинно було стати: створення єдиної дієвої системи державного управління медичним захистом задля збереження життя і здоров'я громадян України, її фінансове, матеріально-технічне та кадрове забезпечення, а також забезпечення координації діяльності іï учасників. Збереження здоров'я та життя громадян країни $є$ однією із найважливіших функцій держави [6, с. 32-33]. Складно заперечити тому, що важливим $\epsilon$ створення єдиної дієвої системи державного управління медичним захистом задля збереження життя і здоров'я громадян України. У цьому сенсі єдиний медичний простір із залученням до нього відомчих медичних закладів був би реальним кроком уперед у справі забезпечення «медичних прав» громадян.

Якщо ми говоримо, що позитивом $\epsilon$ використання військових медичних закладів не тільки для потреб військовослужбовців і членів їхніх сімей, то важливо проаналізувати і зворотні процеси - використання звичайних державних і комунальних закладів охорони для потреб військовослужбовців.

На думку В.О. Жаховського, прикладом реалізації засад єдиного медичного простору є залучення цивільних закладів охорони здоров'я до надання медичної допомоги військовослужбовцям як у мирний час, так i в особливий період. Зазвичай військово-медичні служби в мирний час не можуть у своєму складі відтворювати та дублювати заклади охорони здоров'я, які наявні в системі цивільної охорони здоров'я та при- значені для надання всіх видів високоспеціалізованої високотехнологічної медичної допомоги. За таких умов для надання медичної допомоги військовослужбовцям і ветеранам військової служби за потреби використовуються можливості науково-дослідних клінічних установ Національної академії медичних наук України та інших цивільних високоспеціалізованих закладів охорони здоров'я [7, с. 84].

Події останніх років, що стосуються наявності В Україні тимчасово неконтрольованих територій і спроб повернути їх під всій контроль та український суверенітет, призвели до появи нових категорій громадян - учасників антитерористичної операції (АТО) чи операції об'єднаних сил (ООС). За наявними даними [8, с. 25], станом на 1 листопада 2017 р. налічувалося 319396 учасників АТО, проте звітність щодо їх звернень до закладів охорони здоров' я відсутня, безоплатні ліки вони можуть отримати тільки у близько тисячі аптечних закладів України переважно державної або комунальної форм власності, оскільки приватні аптеки не ризикують укладати з державою відповідні договори. У зв'язку із браком коштів і матеріалів медичні заклади відмовляють учасникам АТО у зубопротезуванні. Щодо вартості тільки щорічного медогляду на 1 особу, то вона складає 300 грн, що майже зовсім покриває встановлений медичною реформою річний тариф на реалізацію конституційного права на охорону здоров'я учасників АТО як громадянам України. Така ситуація викликає серйозні сумніви щодо можливості реалізації ними свої законних прав на пільги у сфері охорони здоров'я у перспективі.

Варто зазначити, що певні фахівці узагалі заперечують доцільність існування відомчої медицини як такої. Наприклад, колишній міністр охорони здоров'я України О. Квіташвілі стверджує: «Водники, академіки, залізничники або шахтарі, які мають свої лікарні, - такі самі люди, як ми з вами. Можливо, специфіка роботи цих установ трохи інша. Можливо, там трохи інша специфіка захворювань, проте загалом люди такі ж, як і ми, з тією ж статурою і набором захворювань. Неможливо, щоб у країні паралельно існували чотири або п'ять систем охорони здоров'я, які працюють по-різному. Природно, всю цю систему з відомчими лікарнями можна зберегти в тому вигляді, в якому вона $\epsilon$. Однак вони повинні працювати за тим же принципом, що і решта лікарень. Єдине, виходячи з того, що в країні війна, я б зробив виняток для військової системи охорони здоров'я, силових структур. Там і система працює по-іншому, і зовсім інша специфіка реакцій на кризові випадки» [9]. Як бачимо, тільки медичній службі Міністерства оборони України колишній керівник профільного медичного міністерства надає «право на життя» поза управлінським впливом Міністерства охорони здоров'я України.

Ще один вимір відомчої медицини - місця несвободи. Державна пенітенціарна служба України, котра втратила статус центрального органу виконавчої влади з 2016 р. і передала свої функції Міністерству юстиції України, має на своєму балансі низку слідчих ізоляторів на декілька десятків колоній. «Незважаючи на певні зрушення у медичному забезпеченні місць позбавлення волі, наведені дані красномовно демонструють неналежне медичне обслуговування засуджених, проблеми із забезпеченням сучасним медичним обладнанням, лікарськими засобами. Забезпечення права на охорону 
здоров'я як засуджених, так і персоналу здебільшого має декларативний характер. Це констатують правозахисники, котрі проводять щорічно моніторинг дотримання прав засуджених, підтверджують практичні працівники. Необхідно констатувати, що досі місця позбавлення волі $\epsilon$ установами з високим ризиком захворювань; смертності, випадків суїциду. Наголошуємо, що такі ризики виникають не тільки у засуджених, а й у персоналу УВП» [10, с. 41]. Така песимістична картина стану справ у пенітенціарній медицині. Проте $\epsilon$ й інші оцінки. Зокрема, О.О. Прасов стверджує, що: 1) особами, засудженими до позбавлення волі, можуть бути реалізовані норми Закону України «Про державні фінансові гарантії медичного обслуговування населення» 3 урахуванням їх правового статусу, режиму відбування покарання; 2) «Порядок організації надання медичної допомоги засудженим до позбавлення волі» підлягає доопрацюванню шляхом відображення у ньому норм Закону України «Про державні фінансові гарантії медичного обслуговування населення» [11, с. 109].

Узагалі ж необхідно враховувати специфіку осіб, котрі перебувають на медичному забезпеченні в медичних установах тюремного відомства. $€$ певні особливості їхніх захворювань. Є.І. Цимбал справедливо стверджує, що питання про правову природу i цілі обов'язкового лікування, його підстави та порядок проведення вимагає спеціального розгляду [12, с. 157]. Засудження особи до покарання, пов'язаного з обмеженням свободи, веде до поміщення ії до установи кримінально-виконавчої системи (арештного будинку, виправного центра, колонії-поселення, виховної або виправної колонії, лікувально-виправної установи або в'язниці). Перебування засуджених у зазначених установах $\epsilon$ вимушеним. Наявність серед засуджених хворих із небезпечними інфекційними захворюваннями становить загрозу для здоров'я оточуючих. Оскільки самі засуджені не можуть вжити заходів для охорони свого здоров'я, ця функція лягає на адміністрацію кримінально-виконавчої установи. Алкоголізм, наркоманія i токсикоманія призводять до психопатизації особистості, а потім - формування органічного недоумства, крім того, для залежності від ПАР характерна наявність патологічного потягу, який може досягати виразу компульсивного, спонукаючи засудженого використовувати будь-які засоби для досягнення сп'яніння. Природно, засуджені з грубими змінами особистості або загостренням потягу до ПАР дезорганізують діяльність кримінально-виконавчих установ.

Чи є узагалі можливим і доречним сприйняття пенітенціарної медицини як складової частини єдиного медичного простору? Чи все ж таки її особливий характер (навіть порівняно з іншими відомчими медичними закладами) робить це неможливим? В.М. Пальченкова зазначає, що, незважаючи на детальну регламентацію дотримання прав засуджених, а саме права на життя, забезпечення особистої безпеки й охорони здоров'я, низка питань залишаються невирішеними. Зокрема, поза увагою залишилися вельми важливі питання, такі як охорона праці (життя та здоров'я при виконанні виробничих завдань). Також, як зазначалося, право на охорону здоров'я включає, крім медичної допомоги, ще й медичне страхування - одне із ключових соціально-економічних прав, гарантованих Конституцією України [13, с. 18]. У контексті останнього варто послатися на фахову оцінку В.Ю. Стеценко, яка стверджує, що «саме страхова медицина здатна суттєво покращити стан справ у вітчизняній охороні здоров'я і забезпечити реалізацію головної мети участі держави в медичній галузі - сприяння реалізації пацієнтами своїх прав, свобод і законних інтересів» [14, с. 12]. Додам від себе: незалежно від належності чи не належності до певних соціальних груп чи професійних спільнот.

Висновки. Таким чином, як видається, відомчі медичні заклади можуть і повинні бути долучені до функціонування єдиного медичного простору. Це дозволить зробити права пацієнтів у сфері медичної діяльності більш реалістичними та такими, що забезпечать рівність і доступність для громадян.

\section{Література}

1. Стеценко С.Г. Соціальна держава: теоретико-методологічні основи дослідження. Право України. 2014. № 2. С. 252-261.

2. Сіделковський О.Л. Правове забезпечення єдиного медичного простору України: до постановки питання. Публічне право. 2018. № 2. С. 126-131.

3. Майданик Р.А. Єдиний медичний простір як ключовий стандарт прав людини і юридичний виклик у сфері охорони здоров'я України. Медичне право. 2013. № 1. С. 33-42.

4. Тихомирова Т.О. Реалізація державної політики охорони здоров ' в в системі МВС України: адміністративно-правовий аспект : автореф. дис. ... канд. юрид. наук : 12.00.07. Держ. НДІ МВС України. Київ, 2010. 20 с.

5. Стеценко С.Г., Тихомирова Т.О. Медичне право України (правове забезпечення відомчої медицини МВC України) : монографія. Київ : Атіка, 2010. 152 с.

6. Бакай А.Є. Міжвідомча взаємодія як інструмент публічного управління галуззю охорони здоров'я в Україні. Аспекти публічного управління. 2017. Т. 5. С. 29-38.

7. Жаховський В.О. Єдиний медичний простір як елемент формування медичного потенціалу держави Україна. Здоров'я нації. 2016. № 4/1. С. 82-86.

8. Солдатенко О.В. Реалізація права на охорону здоров'я учасників АТО у контексті медичної реформи. Проблеми захисту суб'єктів правовідносин у сфері охорони здоров'я в контексті медичної реформи : збірник матеріалів науково-практичного круглого столу (м. Запоріжжя, 25 травня 2018 р.) / за заг. ред. Ю.М. Колесника. Запоріжжя : ЗДМУ, 2018. С. 24-26.

9. Квіташвілі О. Стандартизація за ліжко-місцем - це зло і шкідництво. Економічна правда. 2015. 30 січня. URL: http://www.epravda.com.ua/publications/ 2015/01/30/525533/.

10. Денисов С.Ф., Денисова Т.А. Забезпечення права на охорону здоров'я засуджених та персоналу в умовах позбавлення волі. Конституційні засади медичної реформи в Україні : матеріали Медико-правового форуму (м. Харків, 6 груд. 2019 р.). Харків : Право, 2019. С. 41-42.

11. Прасов О.О. Реалізація особами, засудженими до позбавлення волі, права на вибір лікаря, який надає первинну медичну допомогу: окремі питання. Проблеми захисту суб'єктів правовідносин у сфері охорони здоров'я в контексті медичної реформи : збірник матеріалів науково-практичного круглого столу (м. Запоріжжя, 25 травня 2018 р.) / за заг. ред. Ю.М. Колесника. Запоріжжя : ЗДМУ, 2018. С. 105-110.

12. Цымбал Е.И. Проблемы правового регулирования недобровольного лечения осужденных, больных алкоголизмом и наркоманией. Актуальные проблемы правового регулирования медицинской деятельности : материалы 2-й Всероссийской научно-практической конференции, Москва, 26 марта 2004 г. / под общ. ред. С.Г. Стеценко. Москва : Издательская группа «Юрист», 2004. С. 155-158. 
Актуальні проблеми історико-правової та міжнародно-правової науки

13. Пальченкова В.М. Медична допомога в умовах несвободи. Актуальні проблеми теорї та практики правового регулювання галузі охорони здоров'я: пробле мu $i$ перспективи : збірник матеріалів науково-практичного круглого столу, присвяченого 25-й річниці прийняття Закону України «Основи законодавства України про охорону здоров'я» (17 листопада 2017 р.) / за заг. ред. Ю.М. Колесника. Запоріжжя : Запорізький державний медичний університет, 2017. С. 17-21.
14. Стеценко В.Ю. Організаційно-правові засади медичного страхування: зарубіжний досвід і пропозиції для України. Підприємництво, господарство $і$ право. 2009. № 1. С. 10-13.

Сіделковський О. Л., orcid.org/0000-0002-4139-4478 кандидат медичних наук, директор клініки «Аксімед» (м. Київ) 